\title{
A Plant Process Economic Model for Weed Management Decisions in Irrigated Onion
}

\author{
Claudio M. Dunan, ${ }^{1}$ Philip Westra, ${ }^{2}$ and Frank D. Moore, III $^{3}$ \\ Colorado State University, Fort Collins, CO 80523
}

AdDitional INDEX WORDs. competition; dynamic, ecophysiological, phenominological, process, and simulation model

\begin{abstract}
A simulation model was built as a decision aid for management of five weed species in direct seeded irrigated onion (Allium cepa $L$.). The model uses the state variable approach and simulations are driven by temperature and sunlight as photosynthetically active radiation $(P A R)$. It predicts yield reduction caused by competition for $P A R$ according to the ratio of crop leaf area index (LAI) to weed LAI and respective light extinction coefficients (k). Input variables are plant density by species and average number of leaves by species. Number of leaves per plant is used by the model to provide an estimate of initial leaf area per plant. The model calculates initial species LAIs by multiplying species density times average leaf area per plant. The model accurately describes competitive interactions, taking into account respective plant densities, time of emergence, and time of weed removal. It permits economic evaluation of management factors such as handweeding, chemical weed control, herbicide phytotoxicity due to early application, and control of weed flushes during the season. The model is also used to evaluate mechanisms of plant competition for sunlight. In a sensitivity analysis, onion yield loss was more sensitive to weed $P A R$ interception than to $P A R$ use efficiency, the latter a species-dependent constant in the model.
\end{abstract}

Mathematical models for weed management are being developed as an approach to manage and eventually reduce herbicide use. Yield loss prediction models due to weed competition are needed to evaluate the potential economic return of weed management strategies.

Models that describe and predict the outcome of weed-crop competition range from empirical regression equations to mechanistic models with various levels of resolution (Cousens, 1985; Dunan et al., 1994; Kropff, 1993; Kropff and Spitters, 1991, 1992; Spitters and van den Bergh, 1982; Wiles and Wilkerson, 1991). The type of model and level of resolution depends on the objectives associated with building the model and on the characteristics of the system being studied. If the objective is management, the model should include input variables that growers can easily obtain. Furthermore, a multispecies model provides greater utility. Nevertheless, the model must account for variables that are relevant and significantly impact the system. For example, if the time of weed and crop emergence affects the outcome of competition, then the model should consider these variables.

Building a model entails the formulation of hypotheses about the behavior of the system studied. Under irrigated and fertilized cropping situations, competition among plants has been shown to be mainly for light (Harper, 1977). Our working hypothesis is that weed-crop competition for light explains much of the onion yield reduction due to weed interference. The model presented here is a dynamic, plant process model that simulates the development of onion and weed leaf area index (LAI) to predict crop yield losses due to competition for light. The model is both dynamic and deterministic and follows the state variable principle (de Wit,

Received for publication 27 May 1998. Accepted for publication 18 June 1998. From a dissertation submitted by C.M.D. in partial fulfillment of the $\mathrm{PhD}$ requirement. This research was funded in part by the Organization of American States and the Colorado State Agricultural Experiment Station. We gratefully acknowledge the internal reviews of D.A. Hopper, C.E. Motsenbocker, S.J. Nissen, and L.K Porter. Manuscript processing was by B.M. Schilling and we thank her. The cost of publishing this paper was defrayed in part by the payment of page charges. Under postal regulations, this paper therefore must be hereby marked advertisement solely to indicate this fact.

${ }^{1}$ Graduate, Dept. of Bioagricultural Sciences and Pest Management.

${ }^{2}$ Professor, Dept. of Bioagricultural Sciences and Pest Management; to whom reprint requests should be addressed.

${ }^{2}$ Professor, Dept. of Horticulture.
1970; Forrester, 1961; Thornley and Johnson, 1990).

The objective of this paper is to provide a detailed description of the model structure, its calibration, verification, and validation. Furthermore, we discuss its practical use as an aid to onion growers in making decisions about handweeding, chemical weed control, and control of several weed cohorts over the cropping season. Such applications should ultimately lead to reduction in herbicide usage.

\section{Materials and Methods}

Model DeSCRIPTION. The model is written in Visual Basic and is organized in interactive screens that allow users to enter input data and to view output. Ever since Harper (1977) suggested that in most agricultural systems sunlight drives competition, scientists have designed experiments to study this factor in terms of the weed-crop interface. This model simulates the dynamics of the competition for light between onion and five annual weed species assuming no water or nutrient limitations to plant growth.

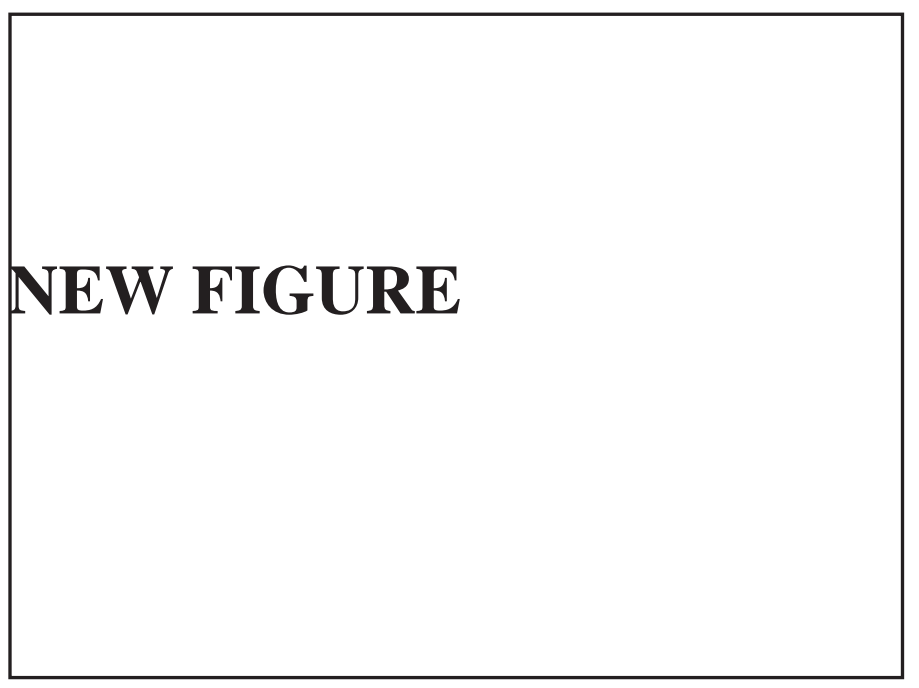

Fig. 1. Flow diagram where DW and LAI represent dry mass and leaf area index summations for each weed species and for onion. Photosynthetically active radiation $(P A R)$ refers to that daily integral intercepted by the canopy. Temperature refers to the mean daily ambient. 
Fig. 2. (a) Relationship between number of leaves per onion plant and plant age in heat units. (b) Relationship between onion plant age and leaf area per plant.

The age of a plant is expressed as thermal time by calculating accumulated heat units (HU) in ${ }^{\circ} \mathrm{C} \cdot \mathrm{d}^{-1}$ using different base temperatures for onion and each of the weed species. The time step $(\Delta \mathrm{t})$ and interval of integration is $1 \mathrm{~d}$.

State variables are weed shoot dry mass and onion shoot dry mass. Onion shoot dry mass is partitioned into leaf and bulb dry mass (OLM and OBM) expressed as grams per square meter of ground area (Fig. 1). Driving variables are daily mean air temp (T) and photosynthetically active radiation $(P A R)$. Daily $P A R$ is estimated as one half of the daily light integral (Charles-Edwards et al., 1986; Thimijan and Heins, 1983). Onion and weed LAIs are calculated by the model. These variables together with species $P A R$ attenuation coefficients, the light extinction coefficients (k) of Monsi and Saeki (1953), are responsible for PAR interception. Onion yield, value of production per hectare, and the benefit of weed control also are predicted by the model.

To calculate the benefit of weed control, two situations are modeled simultaneously: one without weed control and the other with a user-selected weed control tactic. Final production value and costs are compared to predict the economic feasibility of weed control.

Model initialization. The use of species LAI for predicting crop yield reduction due to weed competition was suggested by Kropff (1988). This approach has difficulty in estimating initial LAI values under field conditions. We present a solution to this problem. Onion and weed density per species (plants $/ \mathrm{m}^{2}$ ) and species average number of leaves per plant (leaves/plant) are used to initialize the model. We suggest that using number of leaves per plant to estimate leaf area per plant is a novel and useful approach. Because leaf appearance rate is a function of temperature (Alm et al., 1991), as thermal time, the average number of leaves per plant is used as an indicator of the plant age in HU at time of initialization. Empirical equations estimate plant age in $\mathrm{HU}$ as a function of the number of leaves per plant (Fig. 2a). A functional relationship between HU and leaf area is used to estimate initial leaf area per weed or onion plant (Fig. 2b). Initial species LAI is calculated by multiplying the estimated average leaf area per plant of each species by its respective density.

After estimating the initial age of the plant using the leaf number approach, HU are calculated as follows:

$$
H U=\sum_{i=1}^{n}\left(T-T_{b}\right), T=\frac{T_{\max }+T_{\min }}{2}
$$

where $\overline{\mathrm{T}}$ is daily mean air temperature in degrees Celsius, and $\mathrm{T}_{\mathrm{bi}}$ is the base temperature below which growth, it is assumed, does not take place (Table 1) (Alm et al., 1988; Dunan and Westra, 1991; Wise and Banning, 1987). HU are used to update, on a daily basis, the phenological stage of the species.

DAILY GROWTH RATES. Shoot growth rate of all species is changed on a daily basis according to intercepted $P A R$, ambient temperature, competition for light, and phenology. Maximum growth rate (MGR) is a potential daily rate that is determined by multiplying the variables $P A R$ integral $(P A R)$, fraction of $P A R$ intercepted $(\mathrm{Q})$, and $P A R$ use efficiency $(\mathrm{E})$, as follows:

$$
\mathrm{MGR}=P A R \times \mathrm{Q} \times \mathrm{E}
$$

The fraction of PAR intercepted by the biomass of the ith species growing as a closed canopy monoculture is calculated as $\mathrm{Q}_{\mathrm{i}}=1-\exp \left(-\mathrm{k}_{\mathrm{i}} \times \mathrm{LAI}_{\mathrm{i}}\right)$

where $\mathrm{k}_{\mathrm{i}}$, an empirically derived attenuation constant, represents the canopy PAR extinction coefficient of the ith species (Acock, 1991) and $\mathrm{LAI}_{\mathrm{i}}$ is the leaf area index of the ith species. Reflected $P A R$ from leaves and leaf transmission of $P A R$ are assumed to be negligible. Equation 3 is based on the original Monsi and Saeki equation (1953), $\mathrm{I}=\mathrm{I}_{\mathrm{o}}-\exp (-\mathrm{k} \times \mathrm{LAI})$, expressing their theory of light interception, where sunlight, in this case $P A R$, is attenuated in a $\log$ linear manner as

$\ln \left(\mathrm{I} / \mathrm{I}_{0}\right)=-\mathrm{k} \times \mathrm{LAI}$

where $\mathrm{I}$ and $\mathrm{I}_{0}$ are $P A R$ below and above the canopy, respectively. Therefore, k represents the proportion of $P A R$ penetrating a unit of leaf area occupying that same unit of land area, and therefore $I / \mathrm{I}_{0}$ is fractional $P A R$ penetration. It is recognized that crop and weed height affect light interception but this factor is only indirectly accounted for. The $\mathrm{E}$ is another empirically derived species coefficient like $\mathrm{k}$.

Actual daily shoot growth rate $\left(\mathrm{GR}_{\mathrm{i}}\right)$ of the ith species is a function of $\mathrm{MGR}_{\mathrm{i}}$ and three multiplicative factors. The multiplicative factor approach was suggested by Holt et al. (1975). Each factor (f) is dimensionless and scaled to decrease from unity where $0 \leq \mathrm{f} \leq 1$; $\mathrm{tf}$ is a quadratic function of $\overline{\mathrm{T}}$. The temperature factor (tf) accounts for the effect that air temperature has on plant growth rate. The tf for weed species was derived from data reported by Pearcy et al. (1981). The phenology factor (phf) is indirectly a function of $\mathrm{T}$ according to Eq. [1] and it accounts for changes in $\mathrm{E}$ in Eq. [2] according to

\begin{tabular}{|c|c|c|c|}
\hline Species & Temp $\left({ }^{\circ} \mathrm{C}\right)$ & $\begin{array}{l}\text { Light extinction } \\
\text { coefficient }(\mathrm{k})\end{array}$ & $\begin{array}{c}P A R \text { use } \\
\text { efficiency }(\mathrm{E}) \\
\left(\mathrm{g} \cdot \mathrm{MJ}^{-1}\right)\end{array}$ \\
\hline Allium сера & 7.2 & 0.45 & 2.0 \\
\hline Amaranthus retroflexus & 10.0 & 0.70 & 2.5 \\
\hline Chenopodium album & 6.0 & 0.60 & 2.0 \\
\hline Echinochloa cruss-galli & 9.7 & 0.65 & 2.5 \\
\hline Helianthus annuus & 9.0 & 0.70 & 2.0 \\
\hline Panicum miliaceum & 6.9 & 0.65 & 2.5 \\
\hline
\end{tabular}

Table 1. Base temperatures, light extinction coefficients, and PAR use efficiency of the modeled weed species. 
$\mathrm{GR}_{\mathrm{i}}=\mathrm{MGR}_{\mathrm{i}} \times \mathrm{tf}_{\mathrm{i}} \times \mathrm{phf}_{\mathrm{i}} \times \mathrm{cf}_{\mathrm{i}}$

The competition factor is represented by cf. The model simulates competition for light by distributing the total amount of PAR among weed species and onion in Eq. 6. This distribution is based on respective species LAI, weighted by individual species $\mathrm{k}$ values as follows:

$\mathrm{cf}_{\mathrm{i}}=\mathrm{k}_{\mathrm{i}} \times \mathrm{LAI}_{\mathrm{i}} /\left(\sum_{\mathrm{i}=1}^{\mathrm{n}} \mathrm{k}_{\mathrm{i}} \times \mathrm{LAI}_{\mathrm{i}}\right)$

This approach has been used previously (Dunan et al., 1994; Spitters, 1984; Wiles and Wilkerson, 1991). Interaction among plants is assumed to begin when total LAI of the weed-crop canopy reaches 1.0 (Dunan et al., 1994; Kropff et al., 1993; Wiles and Wilkerson, 1991).

Accumulation of onion together with weed shoot dry mass (M) is determined in a manner similar to that used by Holt et al. (1975):

$\mathrm{M}_{\mathrm{n}}=\mathrm{M}_{0}+\sum_{\mathrm{i}=1}^{\mathrm{n}} \mathrm{GR}_{\mathrm{i}-1} \times \Delta \mathrm{t}$

where $M_{n}$ represents dry mass at $t_{n} M_{0}$ represents dry mass at initialization, $\mathrm{t}_{\mathrm{o}}$, and $\mathrm{GR}_{\mathrm{i}-1}$ is absolute growth rate during the $\mathrm{i}-1$ time step. A time step is represented by $\Delta t$.

Partitioning of biomass. Partitioning of onion shoot dry mass between leaves (OLM) and bulbs (OBM) is achieved by multiplying daily onion shoot growth rate (OGR) by OLMR (LM/M), an empirically derived partitioning coefficient called onion leaf mass ratio, which in turn is a function of crop phenology expressed in HU determined by Eq. [1].

$$
\begin{aligned}
& \Delta \mathrm{OLM}=\mathrm{OGR} \times \mathrm{OLMR} \\
& \mathrm{OLM}=\mathrm{OLM}+\Delta \mathrm{OLM} \\
& \Delta \mathrm{OBM}=\mathrm{OGR} \times(1-\mathrm{OLMR}) \\
& \mathrm{OBM}=\mathrm{OBM}+\Delta \mathrm{OBM}
\end{aligned}
$$

The delta symbol indicates a daily increment of leaf or bulb dry mass.

LAI CALCULATION. Leaf area per plant at time $t\left(\mathrm{LA}_{\mathrm{t}}\right)$ is calculated by the model as

$$
\mathrm{LA}_{\mathrm{t}}=\mathrm{LA}_{\mathrm{t}-1}+\Delta \mathrm{LA}_{\mathrm{t}}-\Delta \mathrm{SNL}_{\mathrm{t}}
$$

where $\mathrm{LA}_{\mathrm{t}-1}$ is the leaf area of the previous day, $\Delta \mathrm{LA}_{\mathrm{t}}$ is the incremental increase in leaf area at time $t$, and $-\Delta \mathrm{SNL}_{\mathrm{t}}$ is the incremental decrease in leaf area due to leaf senescence at time t. For onion, $\Delta \mathrm{LA}_{\mathrm{t}}=\Delta \mathrm{OLM} \times \mathrm{SLA}$, where SLA is the specific leaf area, an auxiliary variable, which is a function of phenology of the species itself. For weed species, $\Delta \mathrm{LA}_{t}=\mathrm{GR}_{t} \times \mathrm{LAR}_{t}$, where $\mathrm{LAR}_{t}$ is the leaf area ratio at time $t$, also a function of phenology of the species. The LAR approach was suggested by Spitters (1989). Leaf senescence rate (LSR) is derived from a fitted function where cumulative species leaf area is regressed on time. Daily loss in an increment of leaf area is calculated for the ith species as

$\Delta \mathrm{SNL}_{\mathrm{i}}=\mathrm{LA}_{\mathrm{i}} \times \mathrm{LSR}_{\mathrm{i}}$

WEed CONTROL. It is assumed that postemergence herbicides (postemergence of weed and crop) for controlling grass weeds reduce the LAI of weeds with no effect on onion at any crop stage. It is also assumed that postemergence broadleaf herbicides reduce weed LAI with no effect on onion if applied after the two-true-leaf stage of the crop. If these herbicides are applied earlier than the two-leaf stage, they reduce onion LA and, as a result, onion plant growth rate based on unpublished research of Dunan and Westra. Phytotoxic effects of postemergence broadleaf herbicides were obtained from experiments where onion leaf area was measured after applying herbicides from flag leaf to the two-true-leaf stage (Dunan, 1994). Herbicide rate, efficacy, and cost of control are inputs to the model.

Handweeding is also considered in the model as a weed control tactic. Handweeding cost is a linear function of weed density and is modeled as a postemergence application with $98 \%$ efficacy (Dunan, 1994).

Agronomic and eConomic variables. Bulb dry mass (OBM) is converted to onion yield (OY) and the gross revenue $(\mathrm{GV})$ in dollars per hectare is calculated by multiplying OY by onion price (OP):

$\mathrm{GV}=\mathrm{OP} \times \mathrm{OY}$

In practice, $\mathrm{GV}$ is calculated with control $\left(\mathrm{GV}_{\mathrm{c}}\right)$ and without control $\left(\mathrm{GV}_{\mathrm{wc}}\right)$. The difference between $\mathrm{GV}$ values is the benefit of control (BC) in dollars per hectare:

$\mathrm{BC}=\mathrm{GV}_{\mathrm{c}}-\mathrm{GV}_{\mathrm{wc}}$

$\mathrm{BC}$ minus cost of control (CC) equals a net margin (NM) of control. When NM is greater than zero, weed control is profitable.

$\mathrm{NM}=\mathrm{BC}-\mathrm{CC}$

\section{Experiments}

Parameterization and calibration of the model were conducted based on the growth analysis of plants growing individually and in monocultures.

GROWTH ANALYSIS OF WEED SPECIES. Growth analysis experiments were used to calculate ratios for partitioning of plant biomass, $\mathrm{E}_{\mathrm{i}}$, and $\mathrm{k}_{\mathrm{i}}$. Sequential harvests of individual plants of common sunflower (Helianthus annuиs L.), lambsquarters (Chenopodium album L.), redroot pigweed (Amaranthus retroflexus L.), wild proso millet (Panicum miliaceum L.), and barnyardgrass (Echinochloa crussgalli $L$.) were performed under field conditions during the spring and summer of 1992 (Dunan et al., 1993). Root, stem, leaf dry mass and leaf area per plant were recorded weekly. Three pregerminated seeds of each species were planted in containers having volumes of $12 \mathrm{~L}$ each. Plants were severed at the soil level, leaf laminae were separated and leaf area was measured. Roots were washed under running water. Separated plant materials were placed in paper bags, dried in a forcedair oven at $70{ }^{\circ} \mathrm{C}$ for $72 \mathrm{~h}$, and dry mass was recorded. Nonlinear regression analysis was performed using the Richards function (Richards, 1959) fitted using a program developed by Nath et al. (1993). Leaf area ratio, SLA, and LMR were calculated and regressed on plant age expressed in HU. Regression of total biomass on accumulated intercepted radiation, was used to calculate $\mathrm{E}$ for each weed species (Russell et al., 1989) where E, the PAR use efficiency index, is the slope of the regression of the cumulative dry matter produced upon the cumulative intercepted PAR (Charles Edwards et al., 1986) where the relationship is best-fit by a straight line. Values of Eused here were calculated from growth analysis experiments and adjusted by further model calibration (Table 1).

Weed monocultures (20 plants $/ \mathrm{m}^{2}$ ) were planted in the field to determine $\mathrm{k}$ values (Table 1). Species LAIs were measured with a portable direct reading plant canopy analyzer (LAI 2000, LI-COR, Lincoln, Neb.) and PAR above and below the canopy was measured with quantum sensors (LI-190 and LI-191; LI-COR) beginning when the canopies reached LAIs of 1 or 2. The Monsi and Saeki (1953) relationship presented in Eq. 4 was used to calculate onion and weed species $\mathrm{k}$ values.

Growth anaLYSIS OF ONION. Growth analysis experiments were performed on onion during 1990, 1991, and 1992 in nine commercial fields near Eaton, Ault, Greeley, and Brighton, Colo. 
Every 2 weeks, 20 onion plants were harvested in each field, leaf laminae were separated from bulbs and leaf area per plant was recorded with a LI-3100. Plant tissues were placed in paper bags and dried at $70{ }^{\circ} \mathrm{C}$ for $96 \mathrm{~h}$ and weighed. Leaf area per plant also leaf and bulb dry mass were regressed (nonlinear regression) on HU. The growth quantities LAR, LMR, and SLA were derived in a manner similar to that described for the five weed species. The $\mathrm{k}$ and $\mathrm{E}$ coefficients for onion were estimated as previously described for weed species.

Time of WeEd ReMoval. These experiments (Oliver, 1988) were performed in five commercial onion fields. Three were performed in 1990 and two in 1991 in Greeley and Brighton, Colorado. These experiments have been reported elsewhere (Dunan et al., 1995; Dunan et al., 1996). Weed removal times were based on onion leaf area development as a function of HU, with a base temperature of $7.2{ }^{\circ} \mathrm{C}$ (Dunan and Westra, 1991). The base temperature was estimated by comparing residual mean squares (RMS) of regressions of onion leaf area on HU using different base temperatures. The base temperature providing the lowest RMS was taken as the estimate of appropriate base temperature. HU were used as an indicator of crop phenology and as a way to reduce variability among locations and years. Six weed removal times were chosen based on rate of increase in leaf area: continuous (weed-free), 100, 400, 700, 1000, 1500 HU, and no removal or fullseason competition $(\approx 2,500 \mathrm{HU})$. Emphasis was placed on determining the effect of weed competition in the early stages of onion growth (100, 400, 700, and $1000 \mathrm{HU})$. The $1500 \mathrm{HU}$ value was chosen because it corresponds to the maximum onion leaf area expansion rate derived during growth analysis experiments (Dunan et al., 1995; Dunan et al., 1996). The experimental design was a randomized complete block with five blocks. Plots were three beds wide ( 76 to $81 \mathrm{~cm}$ each bed) by $3 \mathrm{~m}$ long. Watering, fertilization, and pests (other than weeds) were managed by the growers. Weeds were not seeded; naturally occurring weed populations were used in each field. At each removal time, onion and weed densities, total canopy LAI, and biomass per species were recorded. At harvest, onion yield was determined in one linear meter in the central bed of each plot. Bulbs were weighed and graded according to the size standards of the Colorado Onion Association for yellow onions. These experiments were conducted to verify and validate the model.

Sensitivity Analysis. Values of one parameter or variable are varied while holding all others constant to assess changes in output. This procedure permits identification of factors having the greatest effect on onion-weed competition.

\section{Results and Discussion}

Model Validation. Simulated and observed total onion bulb (all classes) yields, including 95\% confidence bands associated with he observations, are presented in Fig. 3. The graph shows the effect when weeds are allowed to compete over various thermal time periods after planting. Model predictions are within the confidence bands based on the observed values, except when weeds compete from planting to $\approx 900 \mathrm{HU}$ and beyond. The model appears to underestimate yields somewhat when weeds are not removed before this time. The discrepancy may be due to factors not considered in the model such as plant height. However, because growers do not allow weed competition for such an extended period, we feel that model estimated yield loss values are reasonable for the relevant period of weed-crop competition.

Simulated reduction in onion yield (total) as a function of weed density at three different times of weed emergence is shown in Fig.

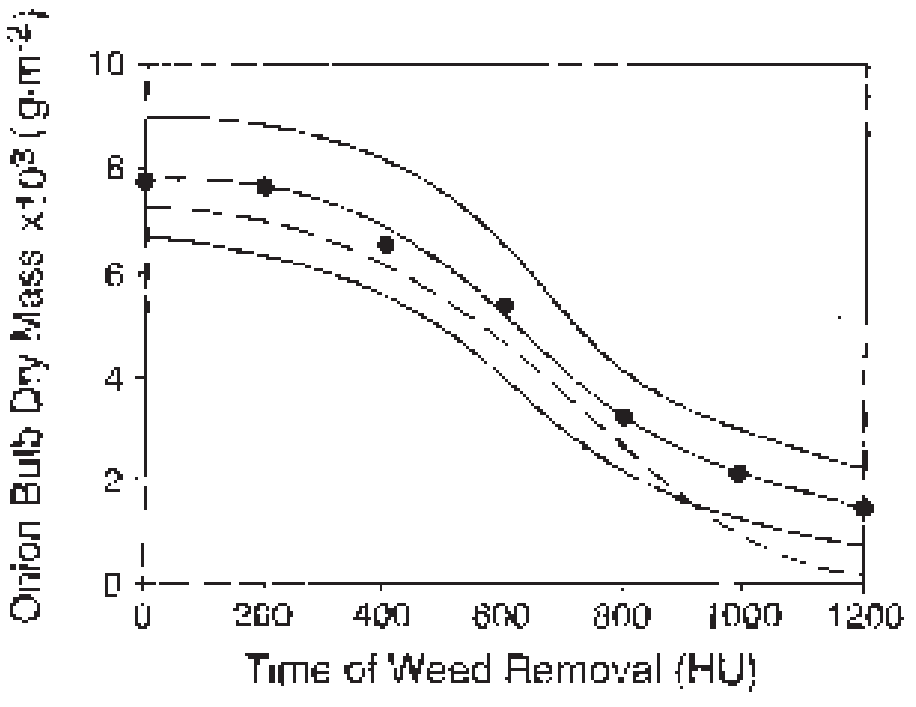

Fig. 3. Comparison of simulated (broken line) and observed (solid line including $95 \%$ confidence bands) onion yield as a function of time of weed removal.

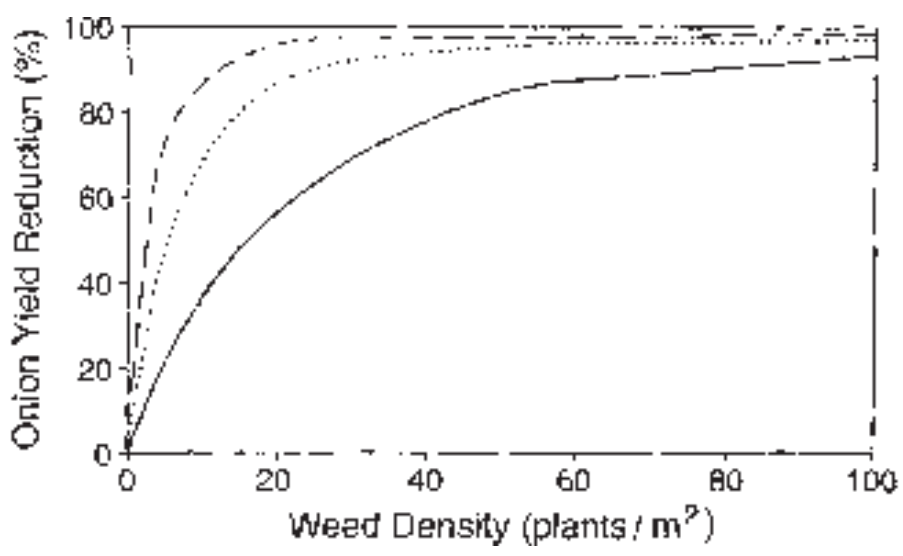

Fig. 4. Simulated onion yield reduction as a function of weed (sunflower, Helianthus annuиs) density. Relative time of weed emergence is expressed as number of leaves per plant: 2 leaves (solid line), 4 leaves (dotted line), and 8 leaves (dashed line). The values chosen represent early, intermediate, and later emergence, respectively.

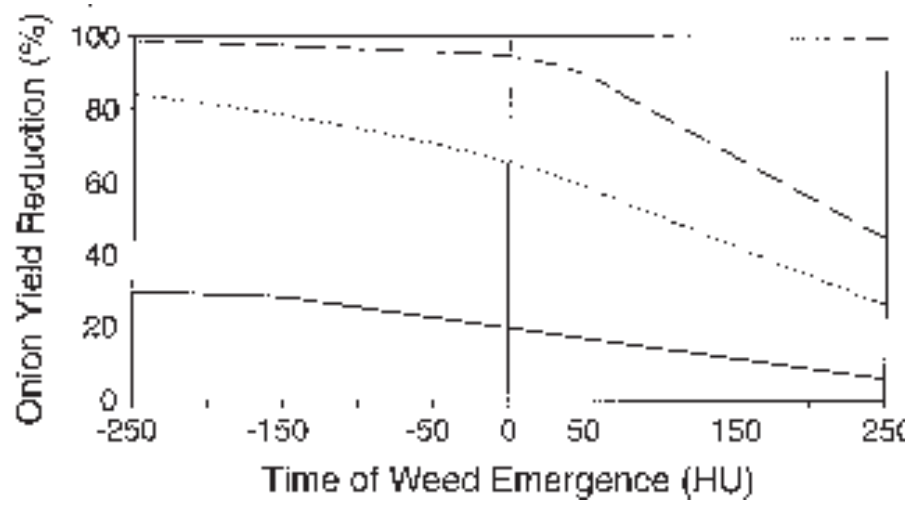

Fig. 5. Simulated onion yield reduction as a function of weed (wild prosso millet, Panicum miliaceum) interference and onion relative time of emergence, expressed in heat units associated with onion plant development. The zero value indicates onion and weeds emerge at the same time. Negative values indicate weeds emerge earlier. Weed densities: 1 plant $/ \mathrm{m}^{2}$ (solid line), 8 plants $/ \mathrm{m}^{2}$ (dotted line), and 20 plants $/ \mathrm{m}^{2}$ (dashed line). 
Table 2. Sensitivity analysis of onion yield to model parameters and variables where changes of $\pm 20 \%$ were instituted.

\begin{tabular}{lcc}
\hline \hline Parameter and variables & Change $(\%)$ & Response $(\%)$ \\
\hline Weed $^{2}$ light extinction coefficient, $\mathrm{k}$ & +20 & -38 \\
& -20 & +510 \\
Weed PAR use efficiency, E & +20 & -40 \\
& -20 & +410 \\
Onion light extinction coefficient, $\mathrm{k}$ & +20 & +4 \\
& -20 & -2 \\
Onion PAR use efficiency, E & +20 & +30 \\
& -20 & -46 \\
Weed density & & \\
Weed size & +20 & -21 \\
Onion density & -20 & +38 \\
Onion size & +20 & -6 \\
& -20 & +6 \\
& +20 & +20 \\
\hline Refers & -20 & -18 \\
& +20 & -4 \\
\hline
\end{tabular}

${ }^{\mathrm{z}}$ Refers to common sunflower, Helianthus annuus.

4. Hyperbolic yield reduction patterns due to weed competition are commonly found in the literature (Cousens, 1985) and have been reported by Dunan et al., 1996. Simulated onion yield reduction as a function of the relative weed and crop times of emergence and three weed densities is shown in Fig. 5. These patterns of behavior have been demonstrated for other weed-crop systems (Cousens and O'Donovan, 1987). Figures 4 and 5 provide model verification in that expected relationships are evident.

Model Sensitivity analysis. Table 2 shows the sensitivity analysis of model parameters and variables. The $\mathrm{k}$ and $\mathrm{E}$ constants for weeds have the greatest impact on onion yield. The great sensitivity of onion yield to these factors is due to the susceptibility of onion to weed competition for PAR. Onion yield was more affected by $P A R$ interception than by E. These results agree with previously reported weed-crop interactions (Kropff and Spitters, 1992; Wiles and Wilkerson, 1991; and Dunan et al., 1993). Onion yield was more sensitive to weed density than to weed size evaluated as number of leaves.

Practical applications of the model. The model permits decision making with regard to control of weed flushes by allowing evaluation of the need for weed control at any time during the cropping season. For example, the model predicts that a common sunflower population density of $10 \mathrm{plants} / \mathrm{m}^{2}$ with an average of 4 leaves per plant competing with 25 onion plants $/ \mathrm{m}^{2}$ with an average of three leaves per plant will result in $83 \%$ yield reduction at the end of the season, if a control tactic is not used soon after the time of survey. A cohort of weeds of equal density and size that emerge when onion has six leaves will reduce crop yield by $5 \%$. The model permits evaluation of the economic impact of any cohort of weeds that emerges over the cropping season. This aspect is crucial for weed management in onion.

Table 3 presents economic benefits and costs of handweeding considering various combinations of weed and crop density and size. Handweeding a redroot pigweed population of $1 \mathrm{plant} / \mathrm{m}^{2}$ averaging 10 leaves per plant is estimated by the model as having a benefit of $\$ 26 /$ ha at a cost of $\$ 12 /$ ha resulting in a net margin of $\$ 14 /$ ha. Handweeding a population of common lambsquarters of similar characteristics results in a net margin close to zero because of the lower competitive ability of lambsquarters relative to redroot pigweed. Our model can help farmers to evaluate the need for handweeding according to weed species and time of emergence, another important factor in weed management.

Postemergence broadleaf herbicides cannot be used in onion before the two-true-leaf stage because of potential phytotoxicity. However, under most field conditions weeds must be controlled before the two true leaf stage to avoid yield reduction (Dunan et al., 1995; Dunan et al., 1996). The decision to control weeds before the two-true-leaf stage and accept some phytotoxicity, or waiting until the two-true-leaf stage and accept longer weed competition, is a common yet difficult one for onion producers. Our model can help with the decision-making process. A sunflower population of 10 plants $/ \mathrm{m}^{2}$ with an average of two leaves per plant, controlled at the 1.3 true leaf stage would have a net margin $15 \%$ lower than delaying the application to the two-true-leaf stage.

The model presented here showed reliability in describing weed-onion competition. It permits evaluation of the impact that weed community composition, weed and crop density, relative time of emergence, and time of weed removal have on weed management decisions. The model has a simple structure using input data easily obtained. The model does not have substrate pool(s) nor does it need any. It does not pretend to be as mechanistic as the models developed by Kropff (1993). It is more phenomenological. However, it does account for relevant variables that affect onion-weed competition such as time of weed emergence, time of weed removal, and weed density. It also aids in making the many weed management decisions that onion producers commonly face such as multiple weed-control decisions throughout the growing season, application of herbicides before the two-trueleaf stage, handweeding, and control of late emerging weeds. The model uses plant density and number of leaves per plant as input variables similar to other bioeconomic models (Lybecker et al., 1991). However, it uses these input variables to initialize weed and onion LAI therefore providing an alternative initialization approach for models where weed-crop competition is predicted as a function of species LAI (Kropff and Spitters, 1991). Validation of

Table 3. Simulated benefits and costs of handweeding as influenced by weed species, weed size, and weed density.

\begin{tabular}{|c|c|c|c|c|}
\hline $\begin{array}{l}\text { Weed } \\
\text { species }\end{array}$ & $\begin{array}{l}\text { Weed density } \\
\left(\text { plants } / \mathrm{m}^{2}\right)\end{array}$ & $\begin{array}{c}\text { Weed size } \\
\text { (leaves/plant) }\end{array}$ & $\begin{array}{l}\text { Benefit } \\
(\$ / h a)\end{array}$ & $\begin{array}{l}\text { Cost } \\
(\$ / h a)\end{array}$ \\
\hline \multirow[t]{3}{*}{ Amaranthus retroflexus } & 0.5 & 10 & 12 & 6.2 \\
\hline & 1.0 & 10 & 26 & 12.4 \\
\hline & 10.0 & 10 & 454 & 124.0 \\
\hline \multirow[t]{3}{*}{ Chenopodium album } & 0.5 & 10 & 9 & 6.2 \\
\hline & 1.0 & 10 & 12 & 12.4 \\
\hline & 10.0 & 10 & 186 & 124.0 \\
\hline \multirow[t]{3}{*}{ Echinochloa crus-galli } & 0.5 & 10 & 15 & 6.2 \\
\hline & 1.0 & 10 & 43 & 12.4 \\
\hline & 10.0 & 10 & 523 & 124.0 \\
\hline
\end{tabular}


the model with actual competition experiments supports the hypothesis that in irrigated and fertilized onion, weed competition is mainly for light.

It has been suggested that biological models may have only heuristic value because accurate and complete validation of biological processes is very difficult, if not impossible (Oreskes et al., 1994). In general we agree with this statement, but from a management perspective, a model like the one presented here can be useful to growers in order to integrate the impact that different biological and economic factors have on weed management decisions in onion. If, due to increasing environmental concerns, onion growers need to justify the use of herbicide, then dynamic decision support models may be an important tool to prove the need for herbicides.

Copies of the onion model and user's manual may be obtained by contacting P. Westra at pwestra@lamar.colostate.edu.

\section{Literature Cited}

Acock, B. 1991. Modeling canopy photosynthetic response to carbon dioxide, light interception, temperature, and leaf traits, p. 41-56. In: K.J. Boote and R.S. Loomis (eds.). Modeling crop photosynthesis from biochemistry to canopy. Spec. Publ. no. 19. CSSA, Madison, Wis.

\section{Notation}

\begin{tabular}{|c|c|c|}
\hline \multicolumn{2}{|l|}{ Symbol } & Units \\
\hline \multicolumn{3}{|c|}{ State variables } \\
\hline M & Weed or onion shoot dry mass & $\mathrm{g} \cdot \mathrm{m}^{-2}$ \\
\hline OLM & Onion leaf dry mass & $\mathrm{g} \cdot \mathrm{m}^{-2}$ \\
\hline OBM & Onion bulb dry mass & $\mathrm{g} \cdot \mathrm{m}^{-2}$ \\
\hline \multicolumn{3}{|c|}{ Generated quantities } \\
\hline LA & Leaf area & $\mathrm{cm}^{2} /$ plant \\
\hline LAI & Leaf area index & \\
\hline Q & Proportion of $P A R$ intercepted & \\
\hline GV & Gross revenue & $\$ /$ ha \\
\hline OY & Onion yield & tonnes/ha \\
\hline OP & Onion price & \$/tonne \\
\hline $\mathrm{BC}$ & Benefit of weed control & $\$ /$ ha \\
\hline NM & Net margin & $\$ /$ ha \\
\hline SNL & Leaf area lost & $\mathrm{cm}^{2} /$ plant \\
\hline \multicolumn{3}{|c|}{ Rates and ratios } \\
\hline MGR & Maximum daily growth rate & $\mathrm{g} \cdot \mathrm{m}^{-2} \cdot \mathrm{d}^{-1}$ \\
\hline GR & Daily growth rate & $\mathrm{g} \cdot \mathrm{m}^{-2} \cdot \mathrm{d}^{-1}$ \\
\hline OLMR & Onion leaf mass ratio & $\mathrm{g} \cdot \mathrm{g}^{-1}$ \\
\hline LAR & Leaf area ratio of weed species & $\mathrm{cm}^{2} \cdot \mathrm{g}^{-1}$ \\
\hline SLA & Specific leaf area of onion & $\mathrm{cm}^{2} \cdot \mathrm{g}^{-1}$ \\
\hline LSR & Leaf senescence rate & $\mathrm{cm}^{2} \cdot \mathrm{m}^{-2} \cdot \mathrm{d}^{-1}$ \\
\hline \multicolumn{3}{|c|}{ Driving variables } \\
\hline $\mathrm{T}$ & Mean daily air temperature & ${ }^{\circ} \mathrm{C}$ \\
\hline$P A R$ & $\begin{array}{l}\text { Approximate photosynthetically active } \\
\text { radiation }\end{array}$ & $0.5\left(\mathrm{MJ} \cdot \mathrm{m}^{-2} \cdot \mathrm{d}^{-1}\right)$ \\
\hline HU & Heat unit & ${ }^{\circ} \mathrm{C} \cdot \mathrm{d}^{-1}$ \\
\hline \multicolumn{3}{|c|}{ Parameters } \\
\hline E & $P A R$ (approximate) use efficiency & $\mathrm{g} \cdot \mathrm{MJ}^{-1}$ \\
\hline $\mathrm{k}$ & Light extinction coefficient & \\
\hline $\mathrm{T}_{\mathrm{b}}$ & Base temperature for growth & ${ }^{\circ} \mathrm{C}$ \\
\hline \multicolumn{3}{|l|}{ Factors } \\
\hline $\mathrm{cf}$ & Competition factor & \\
\hline phf & Phenology factor & \\
\hline $\mathrm{tf}$ & Temperature factor & \\
\hline \multicolumn{3}{|l|}{ Index } \\
\hline I & A subscript indexing species & \\
\hline
\end{tabular}

Alm, D.M., M.E. McGiffen, Jr., and J.D. Hesketh. 1991. Weed phenology, p. 191-218. In: T. Hodges (ed.). Predicting crop phenology. CRC Press, Boca Raton, Fla.

Alm, D.M., D.R. Pike, J.D. Hesketh, and E.W. Stoller. 1988. Leaf area development in some crop and weed species. Biotronics 17:29-39.

Charles-Edwards, D.D. and G.M. Rimmington, 1986. Modelling plant growth and development. Academic Press, New York. p. 198.

Cousens, R. 1985. An empirical model relating crop yield to weed and crop density and a statistical comparison with other models. J. Agr. Sci. 105:513-521.

Cousens, R. and J.T. O'Donovan. 1987. The use of biologically realistic equations to describe the effects of weed density and relative time of emergence on crop yield. Weed Sci. 35:720-725.

de Wit, C.T. 1970. Dynamic concepts in biology, p.17-23. In: J. Setlik (ed.). Prediction and measurement of photosynthetic productivity. Pudoc, Wageningen the Netherlands.

Dunan, C.M. 1994. Ecophysiological approaches to weed management. PhD diss. Colo. State Univ., Fort Collins (diss. abstr. AAC9524025).

Dunan, C.M., F.D. Moore, III, and P. Westra. 1994. A plant process economic model for wild oats management decisions in irrigated barley. Agr. Syst. 45:355-368.

Dunan, C.M. and P. Westra. 1991. Effects of weed competition on onion growth, yield, and quality. Proc. W. Soc. Weed Sci. 44:83 (abstr.).

Dunan, C.M., P. Westra, and P. Miller. 1993. Growth analysis of selected annual weeds commonly found in Colorado irrigated fields. Weed Sci. Soc. Amer. Abstr. 33:138 (abstr.).

Dunan, C.M, P. Westra, F.D. Moore, and P. Chapman. 1996. Modeling the effect of time of weed removal, weed density, and weed competitiveness in irrigated onion. Weed Res. 36:259-269.

Dunan, C.M., P. Westra, E. Schweizer, D. Lybecker, and F.D. Moore. 1995. The concept of early economic period threshold: The case of DCPA in onion. Weed Sci. 43:634-639.

Forrester, J.W. 1961. Industrial dynamics. student version. Mass. Inst. Technol. Press, Cambridge.

Harper, J.L. 1977. Population biology of plants. Oxford Univ. Press, London.

Holt, D.A., R.J. Bula, G.E. Miles, M.M. Schreiber, and R.M. Pearl. 1975. Environmental physiology, modeling and simulation of alfalfa growth. I. Conceptual development of SIMED. Purdue Agr. Expt. Sta. Bul. 75.

Kropff, M.J. 1988. Modelling the effects of weeds on crop production. Weed Res. 28:465-471.

Kropff, M.J. 1993. Mechanisms of competition for light, p. 33-61. In: M.J. Kropff and H.H. van Laar (eds.). Modelling crop-weed interactions. CAB Intl., Oxon, U.K.

Kropff, M.J. and C.J.T. Spitters. 1991. A simple model of crop loss by weed competition from early observations on relative leaf area of weeds. Weed Res. 31:97-105.

Kropff, M.J. and C.J.T. Spitters. 1992. An eco-physiological model for interspecific competition, applied to the influence of Chenopodium album L. on sugar beet. I. Model description and parameterization. Weed Res. 32:437-450.

Kropff, M.J., H.H. van Keulen, H.H. van Laar, and BJ. Schnieders. 1993. The impact of Environmental and genetic factors, p. 137-147. In: M.J. Kropff and H.H. van Laar (eds.). Modeling crop-weed interactions. CAB Intl., Oxon, U.K.

Lybecker, D.L., E.E. Schweizer, and P. Westra. 1991. Computer-aided decisions for weed management in corn. W. J. Agr. Econ. 16:456-460.

Monsi, M. and T. Saeki. 1953. Uber den lichtfaktor in den pflanzengesellschaften und seine bedeutung fur die stoffproduktion. Jpn. J. Bot. 14:22-52.

Nath, S.R., F.D. Moore, III, and K.A. Garret. 1993. User's manual for a portable Unix-based computer program to delineate growth phases using the Richards function. Agr. Expt. Sta. Tech. Bul. TB93-1.

Oliver, L.R. 1988. Principles of weed threshold research. Weed Technol. 2:398-403

Oreskes, N., K. Shrader-Frechette, and K. Belitz. 1994. Verification, validation, and confirmation of numerical models in the earth sciences. Science 263:641-645.

Pearcy, R.W., N. Tumosa, and K. Williams. 1981. Relationships between 
growth, photosynthesis and competitive interactions for a $\mathrm{C}_{3}$ and a $\mathrm{C}_{4}$ carbon plant Chenopodium album, Amaranthus retroflexus. Oecologia 48:371-376.

Richards, F.J. 1959. A flexible function for empirical use. J. Expt. Bot. 10:290-300.

Russell, G., P.G. Jarvis, and J.L. Monteith. 1989. Absorption of radiation by canopies and stand growth, p. 21-39. In: G. Russell, B. Marshall, and P.G. Jarvis (eds.). Plant canopies: Their growth, form, and function. Cambridge Univ. Press, New York.

Spitters, C.J.T. 1984. A simple simulation model for crop-weed competition, p. 355-366. In: Proc. 7th Intl. Symp. Weed Biology, Ecology, and Systematics. CLUMA/EWRS, Paris.

Spitters, C.J.T. 1989. Weeds: Population dynamics, germination and competition, p. 182-216. In: R. Rabbinge, S.A. Ward, and H.H. van Laar (eds.). Simulation and systems management in crop protection. Pudoc, Wageningen.

Spitters C.J.T. and J.P. van den Bergh. 1982. Competition between crops and weeds: A system approach, p. 137-149. In: W. Holzner and M. Numata (eds.). Biology and ecology of weeds. Dr. W. Junk Publishers, The Hague. Thimijan, R.W. and R.D. Heins. 1983. Photometric, radiometric, and quantum light units of measure: A review of procedures for interconversion. HortScience 18(6):818-824.

Thornley, J.H.M. and I.R. Johnson. 1990. Plant and crop modeling. Clarendon Press, Oxford, U.K.

Wiles, L.J. and G.G. Wilkerson. 1991. Modeling competition for light between soybean and broadleaf weeds. Agr. Syst. 35:37-51.

Wise, A.M. and L. Banning. 1987. Calculating the threshold temperature of development for weeds. Weed Sci. 35:177-179. 